\title{
Implementasi Metode Eksperimen dalam Meningkatkan Prestasi Belajar IPA
}

\author{
Ni Made Warsiki* ${ }^{*}$ \\ ${ }^{1}$ SMP N 2 Singaraja, Singaraja, Indonesia
}

\begin{abstract}
Abstrak
This research was conducted in Class IX-13 SMP Negeri 2 Singaraja in odd semester of 2016/2017, with condition of learning achievement of IPA not yet fulfill KKM. The purpose of this classroom action research is to improve students' learning achievement through experimental methods. The method of data collection through the test of learning achievement, which then analyzed by using descriptive method quantitative. The data were presented in the form of average learning achievement and learning mastery procession. The results obtained from this study is the students' learning achievement initially averaged only 73.56 with mastery learning $52.78 \%$, then after the implementation of Cycle I student achievement increased to an average of 79.22 with learning completeness reached 83.33 \%. Cycle II also happened improvement of student achievement reach 79,76 and learning comprehension $86,11 \%$. The conclusion obtained from this research is Implementation of experimental method can improve student achievement in class IX-13 odd semester, academic year 2016/2017.
\end{abstract}

\author{
Keywords: \\ Experiment Method, \\ Learning Achievement
}

\section{PENDAHULUAN}

Sains (IPA) merupakan bagian kehidupan manusia dari sejak manusia itu mengenal diri dan alam sekitarnya. Manusia dan lingkungan merupakan sumber, obyek dan subyek sains. Secara sederhana dapat dikatakan bahwa sains merupakan pengalaman individu manusia yang oleh masing-masing individu itu dirasakan atau dimaknai berbeda atau sama. Oleh karena itu, dengan latar belakang pengalaman yang berbeda, hal serupa mungkin akan dimaknai berbeda oleh individu yang berbeda (Suastra 2009: 1). Hakikat IPA meliputi empat unsur utama yaitu: 1) sikap: rasa ingin tahu tentang benda, fenomena alam, makhluk hidup, serta hubungan sebab akibat yang menimbulkan masalah baru yang dapat dipecahkan melalui prosedur yang benar, 2) proses: prosedur pemecahan masalah melalui metode ilmiah. Metode ilmiah meliputi penyusunan hipotesis, perancangan eksperimen atau percobaan, evaluasi, pengukuran, dan penarikan kesimpulan, 3) produk: berupa fakta, prinsip, teori, dan hukum, 4) aplikasi: penerapan metode ilmiah dan konsep IPA dalam kehidupan sehari-hari. Keempat unsur itu merupakan ciri IPA yang utuh yang sebenarnya tidak dapat dipisahkan satu sama lain. Baker (1992) mengatakan bahwa Pembelajaran Sains materinya lebih ke proses melihat, mengamati, dan melakukan percobaan. Setelah percobaan selesai, siswa dapat menarik kesimpulan sendiri tentang apa yang telah mereka lihat dan amati.Dalam Sains mempelajari semua benda-benda yang ada di permukaan bumi, di dalam perut bumi, dan di luar angkasa, baik yang dapat diamati indera maupun yang tidak dapat diamati dengan indera (BNSP 2006). Trianto (2010) Pada hakikatnya Sains terbagi dalam tiga aspek yaitu Sains sebagai proses yaitu semua kegiatan ilmiah untuk menyempurnakan pengetahuan tentang alam maupun untuk menemukan pengetahuan alam melalui suatu riset ilmiyah.

Pembelajaran di kelas akan berlangsung efektif serta dapat mencapai tujuan pendidikan yang dimaksud, apabila dikemas dengan strategi, metode dan pendekatan yang sesuai dengan pokok bahasan, juga guru memiliki keterampilan memilih media yang sesuai dengan karakteristik mata pelajaran serta peserta didik. Untuk itu guru semestinya memahami peran, fungsi dan kegunaan mata pelajaran diklat yang diampu. Kondisi pembelajaran yang terjadi pada kelas-kelas kita saat ini secara umum, adalah ketidakmampuan guru untuk melaksanakan pembelajaran dengan strategi-strategi, teknik-teknik yang mampu membawa peningkatan prestasi belajar siswa. Kenyamanan guru dalam memanfaatkan strategi pembelajaran konvensional mengakibatkan pembelajaran berpusat pada siswa. Padalah seiring dengan

* Corresponding author.

E-mail Addresses: - warsikimade@gmail.com ( Ni Made Warsiki) 
perubahan paradigma, diharapkan pembelajaran di kelas kita agar senantiasa selalu diupayakan untuk lebih mengutamakan aktivitas siswa sehingga pembelajaran berpusat kepada siswa. Beberapa hal yang menyebabkan guru masih nyaman dengn strategi pembelajaran adalah; kekurang mampuan guru memilih strategi pembelajaran yang tepat sesuai dengan materi yang diajarkan, keengganan melaksanakan inovasi pembelajaran kita saat ini.

Kondisi pembelajaran IPA pada kelas IX-13 SMP Negeri 2 Singaraja jika dilihat dari proses pembelajaran, masih didominasi oleh guru aktivitas guru. Siswa dalam proses pembelajaran kurang mau dan menjadi tidak terbiasa untuk mengambil bagian dalam proses pembelajaran. Materi dan sumber belajar cenderung bersumber dari guru, dan tidak ada kreativitas serta kegiatan-kegiatan membangun pengetahuannya sendiri. Dilihat dari sisi prestasi belajarnya, terlihat bahwa rata-rata prestasi belajar yang diraih oleh siswa kelas IX-13 masih belum dapat mencapai KKM. Hasil penilaian awal yang dilaksanakan menemukan rata-rata prestasi belajar siswa baru mencapai 73,56 dengan ketuntasan belajar 52,78\%. Hasil ini sangat jauh dari KKM yang ditentukan pada sekolah ini adalah 75, dan jika diukur dari kategori yang hasil yang diperoleh tersebut tergolong rendah. Mata pelajaran IPA adalah merupakan salah satu dari mata pelajaran yang di UN-kan, dan kondisi prestasi belajar dimaksud ada pada kelas IX yang sebentar lagi akan mengikuti UN. Dengan demikian kondisi rendahnya prestasi belajar ini merupaka suatu hal yang mendesak untuk segera ditanggulangi.

Untuk mengatasi kesenjangan tersebut, maka guru semestinya mampu memanfaatkan modelmodel pembelajaran sesuai dengan karakteristik mata pelajaran, mampu memotivasi siswa untuk secara maksimal mengikuti proses pembelajaran, sehingga secara serta merta dapat meningkatkan prestasi belajarnya. Saat ini pemerintah sangat gencar untuk meningkatkan kualitas proses maupun hasil belejar siswa lewat proyek-proyek pendidikan dan pelatihan kepada guru, pemberian buku-buku panduan pembelajaran dan memberikan reward kepada guru yang mampu berprestasi. Hal ini mestinya disambut baik oleh para guru kita melalui meningkatkan keterampilannya dalam proses pembelajaran. Keterampilan yang mesti ditingkatkan guru dalam melaksanakan pembelajaran, agar kualitas pembelajarannya dapat meningkat diantaranya; 1) keterampilan memilih strategi pembelajaran yang sesuai dengan materi pelajaran yang sedang diajarkan, 2) keterampilan merangsang tumbuhkembangnya aktivitas dan kreatifitas belajar bagi siswa yang secara serta merta akan berpengaruh terhadap peningkatan prestasi belajar, 3) keterampilan mengadakan variasi proses pembelajaran sehingga tidak membosankan, 4) keterampilan memfasilitasi siswa dalam membangun pengetahuannya sendiri, 5) keterampilan membuka dan menutup pelajaran, 6) keterampilan membimbing diskusi, 7) keterampilan mengelola kelas. Keterampilan-keterampilan ini berhubung dengan kemampuan guru untuk menguasai dasar-dasar pengetahuan yang berhubungan dengan persiapan dan pelaksanaan proses pembelajaran yang akan memberikan dukungan terhadap cara berpikir siswa yang kreatif dan imajinatif.

Dari semua uraian di atas dapat diketahui hal-hal yang perlu dalam upaya meningkatkan aktivitas dan prestasi belajar siswa seperti penguasaan metode-metode ajar, penguasaan model-model pembelajaran, penguasaan teori-teori belajar, penguasaan teknik-teknik tertentu, penguasaan peran, fungsi serta kegunaan mata pelajaran. Apabila betul-betul guru menguasai dan mengerti tentang hal-hal tersebut dapat diyakini bahwa prestasi belajar peserta didik pada mata pelajaran IPA tidak akan rendah.

Oviana (2013) mengatakan bahwa kegiatan pembelajaran dengan metode eksperimen dapat memberikan kesempatan pada siswa untuk menemukan konsep sendiri melalui observasi dengan daya nalar, daya pikir kreatif dan efektif.Darajat 2005. Guru harus menjaga dan menjadikan siswa bergairah menerima pelajaran, dan dia juga harus mengarahkan kelakuan mereka kepada kelakuan yang baik seperti yang diinginkan dan dengan suka rela. Djamarah (2000) berpendapat bahwa Metode eksperimen yaitu metode pemberian kesempatan kepada anak didik secara perorangan atau kelompok untuk dilatih melakukan suatu proses atau percobaan. Johar (2006) mengatakan bahwa kelemahan dari metode eksperimen antara lain tidak cukupnya alat peraga, hal ini mengakibatkan sebagian siswa tidak mempunyai kesempatan untuk mengadakan eksperimen atau percobaaan, jika eksperimen memerlukan jangka waktu yang lama siswa harus menanti untuk melanjutkan pelajaran dan sering mengalami kesulitan dalam melakukan eksperimen dikarenakan guru dan siswa kurang berpengalaman dalam melakukan eksperimen. Martiningsih (2007) Pembelajaran dengan metode eksperimen melatih dan mengajarkan siswa untuk belajar konsep. Dengan demikian, siswa akan menemukan sendiri konsep sesuai dengan hasil yang diperoleh selama pembelajaran. Adapun pengaruh atau efek yang ditimbulkan metode eksperimen terhadap hasil belajar siswa adalah dapat meningkatkan rasa ingin tahu siswa, meningkatkan minat siswa serta dapat meningkatkan prestasi atau motivasi siswa dalam belajar Samatowa (2011). Sanjaya (2006) Adapun langkah-langkah dalam menggunakan metode eksperimen dilalui dengan dua tahap yaitu tahap persiapan,dan tahap pelaksanaan. Silbermen (2006) mengatakan bahwa dengan menggunakan metode eksperimen dalam pembelajaran Sains keaktifan indera dan daya ingatan siswa lebih kuat dibandingkan dengan pembelajaran yang digunakan dengan metode biasa. 
Suprianti (2012) Penggunaan metode eksperimen juga dapat mengembangkan berbagai kemampuan kognitif, afektif dan psikomotor melalui kegiatan-kegiatan seperti mempelajari cara-cara penggunaan alat dan bahan, berusaha mencari dasar teori yang relevan, mengamati percobaan, menganalisis dan menyajikan data, menyimpulkan hasil percobaan, dan mempresentasikan hasil percobaan (membuat laporan) di depan kelas.

Berdasarkan hal tersebut, maka dalam upaya memperbaiki mutu pembelajaran mata pelajaran IPA di kelas IX-13 SMP Negeri 2 Singaraja pada smester ganjil tahun pelajaran 2016/2017 diimplementasikan metode eksperimen. Metode ini diterapkan sebagai upaya menanggulangi permasalahan yang terjadi, mengingat model memiliki karakteristik pembelajaran yang lebih mengutamakan aktivitas, dan kreatifitas siswa secara mandiri, dan guru hanya berfungsi sebagai fasilitator.

Mengacu pada uraian latar belakang tersebut, maka rumusan penelitian ini adalah; Apakah implementasi metode eksperimen dapat meningkatkan prestasi belajar IPA siswa kelas IX-13 SMP Negeri 2 Singaraja pada semester ganjil ahun pelajaran 2016/2017?. Penanggungan permasalahan seperti tersebut, dilaksanakan melalui implementasi metode eksperimen, karena metode ini merupakan suatu cara mengajar di mana siswa melakukan suatu percobaan tentang sesuatu hal, mengamati prosesnya serta menuliskan hasil percobaannya, kemudian hasil pengamatan itu disampaikan ke kelas dan dievaluasi oleh guru. Metode ini sangat searah dengan pemberlakuan kurikulum 2013 yang menggunakan pendekatan saintifik. Dengan melaksanakan pembelajaran melalui metode eksperimen, pembelajaran mempunyai langkah-langkah yang mendorong keaktifan siswa dalam belajar dengan cara memberikan kesempatan bagi siswa seluas-luasnya untuk membangun sendiri pengetahuan yang sedang dipelajari. Penggunaan metode ini mempunyai tujuan agar siswa mampu mencari dan menemukan sendiri berbagai jawaban atau persoalan-persoalan yang dihadapinya dengan mengadakan percobaan sendiri. Juga siswa dapat terlatih dalam cara berfikir yang ilmiah. Dengan eksperimen siswa menemukan bukti kebenaran dari teori sesuatu yang sedang dipelajarinya.

Tujuan penelitian ini adalah untuk meningkatkan prestasi belajar IPA bagi siswa kelas IX-13 SMP Negeri 2 Singaraja pada semester ganjil tahun pelajaran 2016/2017 setelah mengikuti proses pembelajaran dengan menggunakan metode eksperimen. Secara teoritis, hasil penelitian ini diharapkan akan bermanfaat sebagai acuan dalam memperkaya teori dalam rangka peningkatan kompetensi guru. Sedangkan secara praktis penelitian ini diharapkan bermanfaat bagi sekolah, khususnya SMP Negeri 2 Singaraja dalam rangka meningkatkan kompetensi guru mata pelajaran IPA. Di samping itu, penelitian ini juga diharapkan bermanfaat sebagai informasi yang berharga bagi teman-teman guru, kepala sekolah di sekolahnya masing-masing, membuat guru-guru tidak mengajar seenaknya saja. Manfaat secara praktis adalah: (1) Bagi siswa, penelitian ini bermanfaat untuk meningkatkan prestasi belajar, sehingga KKM dapat tercapai, (2) Bagi Guru mata pelajaran IPA, bernmanfaat untuk dapat meningkatkan kompetensi guru dalam mengatasi masalah pembelajaran di kelas. (3) Bagi guru mata pelajaran secara umum, Bermanfaat untuk peningkatan sikap profesionalisme guru, yang akan membantu terjadinya perbaikan pembelajaran serta peningkatan proses pembelajaran di kelas. (4) Bagi sekolah, memperkaya metode, model dan strategi pembelajaran dalam praktiknya untuk meningkatkan kualitas output sekolah.

\section{METODE PENELITIAN}

Mengacu kepada rumusan permasalahan yang disajikan pada bagian sebelumnya, maka penelitian yang dilakukan termasuk penelitian tindakan yang pada intinya bertujuan untuk memperbaiki berbagai persoalan nyata dan praktis dalam peningkatan mutu pembelajaran di kelas, yang dialami langsung dalam interaksi antara guru dengan siswa yang sedang belajar (Suhardjono, Suparno, Supardi, Abdul Azis Hoesein, 2009: 39). Rancangan penelitian tindakan yang digunakan adalah rangcangan penelitian menurut Depdiknas, 2011: 12

Subjek penelitian ini adalah semua siswa kelas IX-13 SMP Negeri 2 Singaraja. Alasan dipilihnya kelas ini sebagai objek penelitian adalah karena permasalahan penelitian ini muncul di kelas ini. Yang menjadi objek penelitian ini adalah peningkatan prestasi belajar siswa dalam pembelajaran IPA setelah diterapkan metode eksperimen. Penelitian ini dilakukan selama 3 bulan yakni; dari bulan Juli 2016 sampai bulan Nopember 2016.

Pengumpulan data penelitian ini digunakan tes prestasi belajar, dengan pelaksanaannya setiap akhir pertemuan melalui posttest, dan test prestasi yang digunakan adalah sesuai dengan instrumen yang telah disusun pada RPP. Metode yang digunakan untuk menganalisis data hasil penelitian ini adalah metode deskriptif kuantitatif. Penyajian data berbentuk Rata-rata nilai prestasi belajar dan ketuntasan belajar. Dalam penelitian ini, tingkat keberhasilan dikur dari rata-rata prestasi belajar siswa yakni bila secara individu telah mencapai sama dengan atau melebihi KKM (75), dan secara klasikal rata-rata ketuntasan belajar telah melebihi $85 \%$. 


\section{ANALISIS DAN PEMBAHASAN}

Permasalahan pokok yang ditanggulangi adalah rendahnya prestasi belajar siswa kelas IX-13 dalam pembelajaran IPA. Melalui hasil ulangan awal ditemukan bahwa prestasi belajar siswa baru mencapai rata-rata 73,56 dengan ketuntasan belajar 52,78\% telah disampaikan pada latar belakang. Kondisi tersebut disebabkan oleh beberapa faktor seperti; strategi pembelajaran yang diterapkan oleh guru masih konvensional, guru masih mendominasi pembelajaran sehingga peserta didik lebih banyak menunggu, guru merupakan satu-satunya sumber belajar. Sedangkan seiring dengan reformasi pendidikan terjadi juga perubahan paradigma pembelajaran yang lebih menekankan pada pembelajaran yang bersifat siswa yang aktif mencaritemukan masalah yang dipelajari, materi pelajaran dibangun sendiri berdasarkan permasalahan yang ditemukan dan kemampuan dasar yang dimilikinya, guru hanya berfungsi sebagai fasilitator proses pembelajaran.

Untuk menanggulanginya, maka diimplementasikan metode eksperimen. Sesuai kaidah dan tahapan penelitian tindakan kelas, maka selanjutnya pada bagian ini disampaikan hasil perencanaan, hasil dari pelaksanaan, hasil observasi/pengamatan dan hasil refleksi, secara rinci berdasarkan penelitian yang dilakukan di SMP Negeri 2 Singaraja.

Perencanaan dimulai dengan menetapkan berbagai alternatif tindakan pemecahan masalah kemudian dipilih tindakan yang paling menjanjikan hasil terbaik dan dapat dilakukan (Suharsimi Arikunto, Suhardjono, Supardi, 2006: 76).Hasil perencanaan meliputi; (1) Peneliti membuat Rencana Pelaksanaan Pembelajaran (RPP) yang akan dilaksanakan dengan metode eksperimen. RPP disajikan pada bagian lampiran. (2) Menyusun permasalahan yang akan diberikan kepada siswa untuk dikerjakan. Masalah disesuaikan deng SK, KD dan materi pelajaran yang sedang dibahas. (3) Menentukan waktu pelaksanaan, yang menyangkut hari, tanggal, sesuai dengan jadwal penelitian yaitu pada minggu ke pertama bulan agustus 2016. (4) Meminta kepada teman-teman guru bidang studi sejenis dan kepala sekolah sebagai mitra kesejawatan dalam pelaksanaan RPP yang sudah direncanakan.

Secara umum proses pembelajaran dilaksanakan mengacu kepada standar proses pembelajaran. Tahapan proses pembelajaran sesuai dengan standar dimaksud adalah meliput tiga tahapan pokok yakni; tahap pembukaan, tahap kegiatan inti dan tahap kegiatan penutup. Didalam ketiga tahapan tersebut, dilaksanakan langkah-langkah pembelajaran dengan metode eksperimen adalah: sebagai berikut. (1) percobaan awal, pembelajaran diawali dengan melakukan percobaan yang didemonstrasikan guru atau dengan mengamati fenomena alam. Demonstrasi ini menampilkan masalah-masalah yang berkaitan dengan materi fisika yang akan dipelajari, (2) pengamatan, merupakan kegiatan siswa saat guru melakukan percobaan. Siswa diharapkan untuk mengamati dan mencatat peristiwa tersebut, (3) hipoteis awal, siswa dapat merumuskan hipotesis sementara berdasarkan hasil pengamatannya, (4) verifikasi , kegiatan untuk membuktikan kebenaran dari dugaan awal yang telah dirumuskan dan dilakukan melalui kerja kelompok. Siswa diharapkan merumuskan hasil percobaan dan membuat kesimpulan, selanjutnya dapat dilaporkan hasilnya, (5) aplikasi konsep, setelah siswa merumuskan dan menemukan konsep, hasilnya diaplikasikan dalam kehidupannya. Kegiatan ini merupakan pemantapan konsep yang telah dipelajari, dan (6) evaluasi, merupakan kegiatan akhir setelah selesai satu konsep.

Tahap pelaksanakan melalui tiga kali pertemuan, Standar Kompetensi memahami berbagai sistem dalam kehidupan manusia., dan Kompetensi Dasar; Mendeskripsikan sistem ekskresi pada manusia dan hubungannya dengan kesehatan. Materi pelajaran meliputi Sistem Ekskresi, Alat-alat yang berfungsi melakukan ekskesi antara lain; Ginjal, Paru-paru, Kulit, dan Hati.

Kegiatan pengamatan dilaksanakan bersamaan dengan proses pembelajaran. Agar pengematan berlangsung efektif serta dengan hasil yang objektif, maka observer dilaksanakan oleh teman guru sejawat. Yang dilakukan oleh observer pada bagian ini adalah; Mencatat semua kegiatan yang terjadi, semua reaksi yang sudah dilakukan, menggunakan tes prestasi untuk mengumpulkan data, mencek tujuan penelitian, indikator keberhasilan penelitian, efektivitas waktu, kegiatan dan proses pelaksanaan, dan membandingkan hasil yang didapat dengan efektivitas proses.

Keberhasilan yang diperoleh siswa/guru dengan menunjukkan hasil rata-rata 79,22. Dari sejumlah 36 subjek penelitian sebanyak 30 orang siswa memperoleh nilai rata-rata sesuai KKM, ada 16 orang siswa memperoleh nilai rata-rata dibawah KKM. Dengan demikian maka ketuntasan belajar siswa baru mencapai 83,33\%. Terhadap siswa yang belum tuntas selanjutnya mereka dibina kembali. Peningkatan prestasi belajar pada siklus I ini terjadi sebanyak 5,66 yakni dari data rata-rata prestasi belajar awal 73,56 ke siklus I menjadi 79,22 merupakan efek positif dari perencanaan, pelaksanaan dan observasi yang telah dilaksanakan. Perencanaan yang dimulai dengan menyusun RPP yang baik dan benar sesuai alur metode eksperimen, dengan melihat kekurangan yang ada sebelumnya, yaitu pembelajaran masih dilakukan 
secara konvensional, belum ada upaya konstruktivisme dan inkuiri. Selanjutya telah terjadi peningkatan hasil walaupun belum maksimal.

Dengan cara yang seksama ini, dapat penulis sampaikan penilaian hasil penelitian ini sudah sesuai harapan, langkah-langkah pelaksanaan di lapangan sudah sesuai teori, walaupun hasilnya belum begitu sempurna dan akan dimantapkan lagi pada siklus berikutnya. Untuk validitas, digunakan validitas hasil dengan perbaikan cara pengajaran untuk memperoleh hasil yang lebih baik, sedangkan reliabiltas yang dipilih adalah dengan penyajian data apa adanya.

Perencanaan siklus I yang sudah matang, dengan membuat RPP sesuai alur problem based learning lebih menuntun siswa mampu meningkatkan kemampuan belajarnya. Pada saat pelaksanaan, peneliti telah mengupayakan agar alur problem based learning berjalan sesuai harapan sehingga siswa betul belajar sesuai harapan model pembelajaran ini. Kendala yang masih ada adalah pola siswa baru mulai diupayakan belajar menggunakan model pembelajaran yang baru dimana para siswa mulai dituntut menemukan sendiri, sedangkan model pembelajaran yang lama masih sifatnya menyuapi. Karena model ini baru mulai dicobakan, para siswa masih tercengang memikirkan kebiasaan yang lama dimana mereka masih senang untuk disuapi. Pengamatan/observasi juga sudah berjalan sesuai harapan walaupun hasilnya belum memenuhi kriteria usulan penelitian mengingat peneliti baru mulai menggunakan model pembelajaran yang baru, dimana guru terkendala dalam merubah kebiasaan pembelajaran konvensional.

Dengan melihat semua hasil yang didapat pada siklus I, baik refleksi data kualitatif maupun refleksi data kuantitatif, maka untuk perencanaan pelaksanaan penelitian di siklus II seperti siklus sebelumnya, demikian jga tahap pelaksanaan sama seperti siklus seblumnya.

Nilai rata-rata yang diperoleh pada siklus II menunjukkan peningkatan dari siklus I yaitu sebanyak 0,54. Pada siklusi I rata-rata prestasi belajar mata pelajaran IPA adalah 79,22 selanjtnya pada siklus II menjadi 79,76. Dari data ini ditemukan 31 siswa atau 86,11 \% ada pada nilai rata-rata diatas KKM yang artinya sudah tuntas, masih ada sebanyak 5 siswa atau 13,89 \% mendapat nilai rata-rata dibawah KKM yang artinya belum tuntas. Siswa yang memperoleh nilai di bawah KKM akhirnya dibina kembali, diberi arahan-arahan, motivasi-motivasi, penguatan-penguatan agar mereka berupaya lebih baik. Secara keseluruhan hasil yang didapat telah memenuhi kriteria keberhasilan penelitian sehingga tidak diterikan lagi ke siklus berikutnya.

Perencanaan siklus II yang sudah matang, dengan membuat RPP sesuai alur metode eksperimen lebih menuntun siswa mampu meningkatkan kemampuan belajarnya. Pada saat pelaksanaan, peneliti telah mengupayakan agar alur metode eksperimenberjalan sesuai harapan sehingga siswa betul belajar sesuai harapan metode pembelajaran ini. Pengamatan/observasi juga sudah berjalan sesuai harapan walaupun hasilnya belum memenuhi kriteria usulan penelitian mengingat peneliti baru mulai menggunakan model pembelajaran yang baru.

Penelitian yang dilakukan pada siklus berikutnya yaitu siklus II dimulai lagi dari perencanaan, pelaksanaan, observasi dan refleksi. Penilaian terhadap hasil perencanaan daapt disampaikan bahwa RPP yang dibuat sudah sesuai dengan harapan metode eksperimen. Ini bisa dilakukan dengan baik karena peneliti sudah berpengalaman membuat RPP metode eksperimen sebelumnya yaitu pada siklus I. Pelaksanaan yang sudah cukup mantap dapat dilakukan seuai alur yang tertera pada bagian teori, begitu juga observasi/pengamatan berjalan sesuai harapan. Setelah direfleksi ternyata hasil yang diperoleh sudah sesuai dengan usulan keberhasilan penelitian, sehingga dapat dinilai bahwa pelaksanaan penelitian pada siklus II ini sudah cukup memuaskan.

Kondisi tersebut disebabkan karena perencanaan, pelaksanaan dan observasi siklus I adalah; kegiatan pemecahan permasalahan yang diberikan oleh guru kepada siswa untuk dikerjaka pada kelompok belajarnya, dilanjutkan dengan presentasi telah memberikan efek positif memforsir siswa untuk betul-betul dapat memahami apa yang sudah dipelajari. Nilai rata-rata siswa di siklus I sebesar 79,22 dengan ketuntasan belajar 83,33 \% menunjukkan bahwa siswa telah menguasai materi yang diajarkan walaupun belum begitu sempurna. Hasil ini menunjukkan peningkatan kemampuan siswa menguasai mata pelajaran IPA, Apabila dibandingkan dengan nilai awal siswa sesuai data yang sudah disampaikan dalam analisis sebelumnya.

Hasil tes prestasi belajar di siklus I telah menemukan efek utama bahwa penggunaan metode tertentu akan berpengaruh terhadap prestasi belajar siswa yang dalam hal ini adalah metode eksperimen. Hal ini sesuai dengan hasil meta analisis metode pembelajaran yang dilakukan oleh Soedomo (1989/1990) yang menyatakan bahwa metode pembelajaran yang diterapkan oleh seorang guru berpengaruh terhadap prestasi belajarnya.

Kendala yang masih tersisa yang perlu dibahas adalah prestasi belajar yang dicapai pada siklus I ini belum memenuhi harapan sesuai dengan kriteria keberhasilan penelitian yang diusulkan pada mata pelajaran IPA di sekolah ini yaitu 75. Oleh karenanya upaya perbaikan lebih lanjut masih perlu diupayakan sehingga perlu dilakukan perencanaan yang lebih matang untuk siklus selanjutnya. 
Hasil yang diperoleh dari tes prestasi belajar di siklus II menunjukkan bahwa kemampuan siswa dalam mengikuti pelajaran sudah cukup baik. Ini terbukti dari rata-rata nilai siswa mencapai 79,76 dengan ketuntasan belajar $86,11 \%$. Hasil ini menunjukkan bahwa metode eksperimen telah berhasil meningkatkan kemampuan siswa menempa ilmu sesuai harapan. metode eksperimen merupakan metode yang cocok bagi siswa apabila guru menginginkan mereka memiliki kemampuan berkreasi, berargumentasi, mengeluarkan pendapat secara lugas, bertukar pikiran, berargumentasi, mengingat penggunaan metode ini adalah untuk memupuk kemampuan berbicara dihadapan orang banyak.

Setelah dibandingkan nilai awal, nilai siklus I dan nilai siklus II, terjadi kenaikan yang signifikan, yaitu dari rata-rata nilai awal adalah 73,56 dengan ketuntasan belajar 52,78\% naik di siklus I menjadi 79,22 dengan ketuntasan belajar 83,33\% dan di siklus II naik menjadi 79,76 dengan ketuntasan belajar $86,11 \%$. Kenaikan ini tidak bisa dipandang sebelah mata karena kenaikan nilai ini adalah dari upayaupaya yang maksimal yang dilaksanakan peneliti demi peningkatan mutu pendidikan dan kemajuan pendidikan khususnya di SMP Negeri 2 Singaraja.

\section{KESIMPULAN}

Dari hasil penelitian seperti yang telah diuraikan pada bagian sebelumnya, dapat disimpulkan bahwa implementasi metode eksperimen dapat meningkatkan prestasi belajar IPA siswa kelas IX-13 SMP Negeri 2 Singaraja smester ganjil tahun pelajaran 2016/2017.

Berdasarkan simpulan penelitian ini, maka berikut ini disampaikan saran-saran sebagai berikut; (1)Dalam melaksanakan proses pembelajaran pada mata pelajaran IPA, penggunaan metode eksperimen semestinya menjadi pilihan dari beberapa metode yang ada mengingat metode ini telah terbukti dapat meningkatkan kerjasama, berkreasi, bertindak aktif, bertukar informasi, mengeluarkan pendapat, bertanya, berdiskusi, berargumentasi dan lain-lain. (2) Walaupun penelitian ini sudah dapat membuktikan efek utama dari metode eksperimen dalam meningkatkan aktivitas dan prestasi belajar, sudah pasti dalam penelitian ini masih ada hal-hal yang belum sempurna dilakukan, oleh karenanya kepada peneliti lain yang berminat meneliti topik yang sama untuk meneliti bagian-bagian yang tidak sempat diteliti. (3) Selanjutnya untuk adanya penguatan-penguatan, diharapkan bagi peneliti lain untuk melakukan penelitian lanjutan guna verifikasi data hasil penelitian.

\section{DAFTAR PUSTAKA}

Adnyana, Putu Budi, Desak Made Citrawathi, Putu Artawan .2017.Pelatihan Pembuatan Media Pembelajaran Ipa Sd Berbasis Eksperimen Bagi Guru Guru Sd Gugus Viii Kecamatan Kubutambahan International Journal Of Community Service Learning Vol 1, No 2 (2017): Agustus 2017

Arikunto, Suharsimi; Suhardjono; Supardi. 2006. Penelitian Tindakan Kelas. Jakarta: PT Bumi Aksara.

Arimbawa , P. A., I Wayan Santyasa, Ni Ketut Rapi. 2017. Strategi Pembelajaran Guru Fisika: Relevansinya Dalam Pengembangan Motivasi Belajar Dan Prestasi Belajar Siswa. Wahana Matematika dan Sains: Jurnal Matematika, Sains, dan Pembelajarannya Vol 11, No 1 (2017): April 2017.

Baker, 1992. Teknik Mengajar Secara Sistematis, Jakarta: Rineka Cipta.

BSNP. 2006. Pedoman Penyusun KTSP, Jakarta: Depdiknas.

Daradjat, Zakiah. 2005. Kepribadian Guru, Jakarta: BulanBintang.

Djamarah, Syaiful Bahri. 2000. Metode Pembelajaran, Jakarta : Rineka Cipta,.

-, 2000. Guru dan Anak Didik dalam Interaksi Edukatif, Jakarta: Rineka Cipta.

Handayani , Ni Nyoman Lisna. 2017. Pengaruh Model Self-Directed Learning Terhadap Kemandirian Dan Prestasi Belajar IPA Siswa Kelas VIII SMP N 3 Singaraja. Jurnal Imiah Pendidikan dan Pembelajaran Vol 1, No 1 (2017): Maret 2017. 
Indrawan, Putu Oktap. 2017. Prestasi Belajar Siswa Dalam Diklat Lesson Study. JPI (Jurnal Pendidikan Indonesia) Vol 6, No 1 (2017).

Johar, Rahmah, dkk. 2006.Strategi Belajar Mengajar, Banda Aceh: FKIP Unsyiah,

Martiningsih.2007. "Macam-Macam Metode Pembelajaran" [online]. Dalam http://martiningsih.blogspot.com/2007/12/macam-macam-metode pembelajaran.html

Miles, Matthew, B. Dan A. Michael Hubberman. 1992. Analisis Data Kualitatif. Terjemahan Tjetjep Roheadi Rohidi. Jakarta: Penerbit Universitas Indonesia.

Nida, I Gd.W. 2014. Pengaruh Model Pembelajaran Kooperatif Tipe TPS (Think Pair Share) Berbantuan Peta Konsep Terhadap Prestasi Belajar Fisika. Wahana Matematika dan Sains: Jurnal Matematika, Sains, dan Pembelajarannya Vol 8, No 2 (2014): Oktober 2014.

Noge, Maria Desidaria. 2018. Penerapan Model Pembelajaran Bilingual Preview-Review Berbasis EFlashcard untuk Meningkatkan Aktivitas dan Prestasi Belajar Bahasa Inggris Siswa SMP. Journal of Education Technology Vol 2, No 1 (2018).

NK, Roestiyah. 2001.Strategi Belajar Mengajar, Jakarta: Rineka Cipta,

Oviana, Wati dan Maulidar. 2013. Penggunaan Metode Eksperimen Pada Pembelajaran Materi Sifat Bahan Dan Kegunaannya Terhadap Hasil Dan Respon Belajar Siswa Kelas Iv Min Tungkob Aceh Besar. Jurnal Ilmiah DIDAKTIKA Februari 2013 VOL. XIII, NO. 2, 336-350

Rismaningsih , Febri. 2016. Perbedaan Penggunaan Metode Eksperimen Dengan Pendekatan Inkuiri Dan Verifikasi Terhadap Hasil Belajar Siswa Jurnal Pendidikan Dan Pengajaran Vol 49, No 3 (2016): Oktober 2016

Rismaningsih, Febri. 2008. Perbedaan Penggunaan Metode Eksperimen Dengan Pendekatan Inkuiri Dan Verifikasi Terhadap Hasil Belajar Siswa Jurnal Pendidikan Dan Pengajaran Vol 41, No 4 (2008): Edisi Khusus 2008

Samatowa, Usman. 2011. Pembelajaran IPA di Sekolah Dasar, Jakarta: PT Indeks,

Sanjaya, Wina. 2006. Strategi Pembelajaran, Jakarta: Media Grafika,

Setiawan, Y. Z.. 2015. Pengaruh Motivasi Belajar Dan Lingkungan Belajar Terhadap Prestasi Belajar Fisika Kelas X Sma Negeri Di Kecamatan Mendoyo Tahun Ajaran 2014/2015 Wahana Matematika dan Sains: Jurnal Matematika, Sains, dan Pembelajarannya Vol 9, No 2 (2015): Oktober 2015

Silbermen, Mevin L. 2006. Aktif Learning, 101 Cara Belajar Siswa Aktif, Bandung: Nusa Media,

Slavin, Robert E. 1995. Cooperative Learning: Theory, Research, and Practice. Boston: Allyn and Bacon.

Sukreni , Ni Wyn., Md. Sumantri, I Kt. Dibia. 2013. Hubungan Antara Latar Belakang Sosial dan Motivasi Belajar Terhadap Prestasi Belajar pada Siswa Kelas V SD Negeri 10 Sanur. Mimbar Pgsd Undiksha Vol 1, No 1 (2013).

Suprianti, Dhian, "Penggunaan Metode Eksperimen Dalam Pembelajaran IPA"[online].http://dhiasuprianti.wordpress.com/penggunaan-metodeeksperimen-dalampembelajaran-ipa/.

Sudjana, Nana. 2002. Penilaian Hasil Proses Belajar Mengajar. Bandung: PT Remaja Rosdakarya.

Suhardjono. 2010. Pertanyaan dan Jawaban di Sekitar Penelitian Tindakan Kelas \& Tindakan Sekolah. Malang: Cakrawala Indonesia. 
Syah, Muhibuddin, (Ed), 2005. Psikologi Pendidikan dengan Pendekatan Baru, Bandung: Remaja Indonesia,

Trianto, 2010. Model PembelajaranTerpadu, Jakarta: Bumi Aksara,

,2011. Mendesain Model Pembelajaran Inovatif-Progresif, Jakarta: Kencana,

Tim Prima Pena. Kamus Besar Bahasa Indonesia. Gramedia Press. 